\title{
Democracy and Democratization: Case Study of Formation of Democracy in Latvia
}

\author{
Inese Abolina \\ University of Latvia, Riga, Latvia
}

\begin{abstract}
In August 21, 1991 Latvia started new direction to the people of Latvia; they now had to learn to establish relations on a new basis. The transformation could not occur on a single date. The totalitarian regime began to collapse as early as in 1987 with the liberalization processes in the economy and politics. It continued with the formation of political movements and parties. The declaration of an independent state on May 4, 1990, began a transition period to complete independence and to a start of the democratic regime and democratization. Latvia's Constitution Satversme Article 1 states that Latvia is a democratic Republic. It means that one of the constitutional identity elements is based on democracy. The most important person in a democracy is a loyal citizen with freedom to form and join organizations and political parties, freedom of expression, right to vote, information source diversity, free and open elections and freedom of choice. This paper examines the following questions: how political leaders perform in democratization process, about vision and mission of political leaders; whether those leaders who were known at the beginning of democratization process are also on a political scene currently, during consolidation process of democracy. Also institutions which are established in order to develop the formation of democratization are mentioned as a necessity for supervision of the democratic state. The paper evaluates the political responsibilities of the leader and how the formation of democracy is stated in different government declarations. The paper aims to conclude about the performance of leaders in democratization process.
\end{abstract}

Keywords: democracy, freedom, elections, leaders

\section{Introduction}

In August 21st, 1991 Latvia started new direction to the people of Latvia; they now had to learn to establish relations on a new basis. The transformation could not occur on a single date. The totalitarian regime began to collapse in 1987 and Latvia was on its way to regain its independence from the Union of Soviet Socialist Republics (USSR) and to start the liberalization processes in the economy and politics. It continued with the formation of political movements and parties.

The paper examines how political leaders perform in democratization process, about vision and mission of political leaders; whether those leaders who were known at the beginning of democratization process are also on a political scene currently, during consolidation process of democracy. The paper evaluates the political responsibilities of the leader and how the formation of democracy is stated in different government declarations.

Inese Abolina, Ph.D. student, Political Science Department, Faculty of Social Sciences, University of Latvia. 
The paper concludes about the performance of leaders in democratization process and how it influences the formation of democracy in Latvia.

\section{Commitment to Democracy}

As stated by the President of the United States of America Abraham Lincoln (1809-1865), democracy is government of the people, by the people, for the people (Maiolo, 2007, p. 118). This strengthens the definition of democracy which idea is a form of community that rightly governs itself and determines its own future (Held, 1996, p. 352). Democracy is a very challenging form of government, it obliges both political leaders and people. It is a form of government in which people rule and this has been debated for several centuries (Sorensen, 1993, p. 3). Majority of democratic countries are republics where politicians are elected in fair and free elections by people, which is guaranteed by constitution.

There are also weaknesses in democratic regime. Former British Prime Minister Sir Winston Churchill (1874-1965) says, that no one pretends that democracy is perfect or all-wise. Indeed, it has been said that democracy is the worst form of government except all those other forms that have been tried from time to time. There is no such thing as the "perfect form of government" on earth, but any other form of government produces even less desirable results than democracy. Until today, no other form of government has been invented that could regulate public affairs better than democracy.

Democracy has been widely mentioned in contemporary political discourse. Robert Dahl (1915-2014), one of the most significant political theorists, defines democracy as a political system with effective participation, voting equality, enlightened understanding, control of the agenda, inclusiveness. According to Dahl (2000), democracy produces desirable consequences, such as, avoiding tyranny, essential rights, general freedom, self-determination, moral autonomy, human development, protecting essential personal interests, political equality, peace seeking and prosperity (p. 45).

In order the country to be called a democracy, it needs to fulfil the requirements, which are not only be written down in constitution, but must be kept up in everyday life by politicians, political leaders, and people. Requirements for democracy are:

(1) To guarantee the human rights to every person in relation to the state, social groups, religious institutions, and other persons;

(2) To ensure freedom of opinion in speech, press and mass media;

(3) To have religious freedom and tolerance;

(3) To have general and equal rights to vote (one man/woman, one vote);

(4) To have good governance (a focus on public interest and absence of corruption);

(5) To have effective participation of citizens;

(6) People should have the opportunity to decide on the political matters.

Democracy is open and transparent to the society, or at least it should be. The political system, politicians and leaders are controlled and criticized by voters, press and media.

Robert Dahl has strengthened that the political leaders, the elite has the main role to determine the political discourse of the state and it determines the political culture in the country. This leads to analyse and understand the importance of political leaders at the beginning of the renewal of the independence of Latvia and development of democracy, because exactly these leaders formed the political culture of the country for that period and later when the country operates as a democratic, national state. It was important to build such a 
political culture in Latvia that people would believe that they can influence the decisions made by the political elite, and that this belief is turned into actual activities of influence. Also the attitude towards the values of democratic culture and political processes describing political culture were important to implement at the early stage of renewal of independence and formation of democracy. Democracy is in people's minds, the formation of that it is closely related with the attitude and with the thinking.

\section{The Formation of Democracy}

The formation of democracy in Latvia allowed people to have open judgements, critics, share of experience and can be considered as the best model of state administration. Vaira Paegle, former Chairperson of the Saeima (Parliament of Latvia) Foreign Affairs Committee, addressed the Conference Development of Democracy (August 2006) delegates with a question of the philosopher John Locke, whether the test of democracy is the avoidance of extremism and immunity from it. The answer is, not only. She continued, that the democracy is a work in progress, an ideal to be striven for, even if never achieved. It is a state of mind based on an understanding of the meaning of the common good, of compromise, of tolerance and respect for the opinions of others, no matter how different from our own. Most significantly, democracy requires the fusion of freedom and responsibility. Democracy is not unfettered freedom as some would like to define it - it is taking responsibility for one's actions, political and personal, as well as guaranteeing the freedom of action of others. Democracy is still the best hope for peace and prosperity in the world. Referring to Ivars Godmanis, former Prime Minister of Latvia, democracy is relations between people, based on respect, tolerance, observing rights to freedom, but without destructing freedom of other people.

Already in 1987 the Human Rights group Helsinki 86 were formed. Helsinki 86 had an important role during the liberalization process in Latvia. As the paper examines how political leaders become and how they performed in democratization process, about their vision and mission, and whether those leaders who were known at the beginning of democratization process are also on a political scene currently, during consolidation process of democracy, I would like to mention leaders from Helsinki-86, like the founders Linards Grantinšs, Raimonds Bitenieks, Mārtiņš Bariss and members like Rolands Silaraups, Konstantins Pupurs, Juris Vidiņš, Juris Ziemelis, Alfreds Zariņš, Heino Lāma, and Edmunds Cirvelis. Democracy allows people to have different views, and democracy makes it also responsible for negotiating an answer for those views. This was the main target for those leaders to express their views and wishes for the independent and democratic country. Unfortunately, none of them are on the political stage currently. This group organized the first anti-Communist demonstration with flower placing at the Monument of Freedom in Riga and this event has been mentioned as the rebirth of national courage. In August 1987, the same group organized the protest demonstration against the Molotov-Ribbentrop Pact, by which Latvia was occupied by Soviet Union in 1940. As from 1989, this date is known as Baltic Way or Baltic Chain were around two million people are joining hands and forming a human chain of $700 \mathrm{~km}$ across the three Baltic States-Estonia, Latvia and Lithuania.

The most important and the largest (around 250,000 members) group at that time of political change were formed in 1988 called Latvijas Tautas fronte (Popular Front of Latvia). That was established as a political organization in Latvia which led Latvia to its independence from the Soviet Union. The leader of Latvijas Tautas Fronte was Dainis Ivvans. Tautas fronte was supported by the political leader of that time, Head of State Anatolijs Gorbunovs. Anatolijs Gorbunovs has been the political leader in Latvia during the formation of democracy and was acting as the Head of State during the process of the regaining of independence and the 
establishment of new democratic regime, which led to formation of political parties and elections. In December 1989 and March 1990, the first free elections were held in Latvia since 1933. After the Popular Front victory in the 1990 election, the leader of Latvijas Tautas Fronte, Dainis Ivvans became the deputy speaker of the Supreme Council, the transitional Parliament of Latvia. $81.3 \%^{1}$ of inhabitants with voting rights participated in these elections. He resigned from this position in 1992, but in 1998, Ivans returned to politics by joining the Latvian Social Democratic Workers' Party and was elected to Riga City Council from the Social Democrats' list in 2001. He was the leader of the Latvian Social Democratic Workers' Party from 2002 to 2005. Also currently Dainis Īvāns should be mentioned as a significant leader for Latvia's independence. After 25 years of independence of Latvia, he published a book Gara spēka zemes atgūšana how during the restoration of independence two ideologically different groups were fighting again each other: Popular Front of Latvia and Interfront. Dainis Ivāns has played an important role to establish democracy in Latvia.

Two political groups were formed. One, Latvijas Tautas Fronte, group (134 deputies out of 201) was for the independence of Latvia and economic reforms while another group "Līdztiesība" (57 deputies out of 201, a part of Interfront) strictly forced the idea of socialism and membership in USSR. Soon the split happened in Latvian Communist Party and two strong political leaders Alfrēds Rubiks and Ivars Ķezbers (Latvias Independent Communist Party, national communists) started leading their wings. Alfrēds Rubiks, well known leader under Soviet times, the Chairman of the Executive Committee of the Riga City Soviet from 1984 to 1990. He was the last Communist Mayor of the Riga City. He was member of the Politburo of the Communist Party of the Soviet Union from July 1990 until its abolition on August 24, 1991. As head of the Communist Party of Latvia in 1991 he opposed Latvia's independence from the Soviet Union, and was imprisoned in July 1995 for his role in attempting to overthrow the newly established democratic government and supporting the August 1991 coup d'état attempt in Moscow. Despite his incarceration, Alfrēds Rubiks was a candidate in the 1996 election for the President of Latvia, but lost to incumbent Guntis Ulmanis. Rubiks was released in November 1997 for indulgence and very soon became the Chairman of the Socialist Party of Latvia, the successor to the Communist Party, in 1999 and from the Socialist Party of Latvia he was elected a Member of the European Parliament in the 2009 European Parliament elections. Due to his former allegiance with the Communist Party of Latvia after January 1991, Alfrēds Rubiks is prohibited from running for an electable office in Latvia under the Latvian law.

Ivars Ķezbers was politician and had Ph.D. in history. His role during restoration of independence was high due to the fact that he was a leader of the Independent Communist Party, which later were renamed to Latvia's Democratic Workers Party and as from 1994 he was the leader of joined political group called Democratic Party Saimnieks. He passed away at the age of 53 during the business trip in Strasbourg, but still he has been mentioned in different articles as a great political leader of times of restoration of independence and democracy formation in Latvia.

Also in July 1988, the political organization LNNK (Latvijas Nacionālā Neatkarības Kustība; Latvian National Independence Organisation) were formed and the Board of 14 people were elected. The Board members were: Eduards Berklavs, Jānis Biezais, Juris Dobelis, AivarsJakovičs, Roberts Kḷimovičs, Juris Lomonovskis, Visvaldis Mucenieks, Andris Pauls-Pāvuls, Einars Repše, Diāna Repše, Anta Rudzīte, Dans Titavs and Valts Titavs. The target for this organization was to renew the suvereignity of the Republic of Latvia,

\footnotetext{
${ }^{1}$ Retrieved June 1, 2016, from http://lnvm.lv/?p=4428
} 
to establish the status of Latvian language as a native language, to establish national troops units, to renew symbols of Latvia. ${ }^{2}$ This political organization has grown and developed as a strong national political party and currently it is one of the leading political parties in Latvia. From the above mentioned leaders, Einars Repše has been the Prime Minister of Latvia and also the President of the Latvijas Banka (Bank of Latvia).

Previously prohibited gatherings started to take place one after another. The declaration of an independent state on May 4, 1990, began a transition period to complete independence, start democratization process and build democratic regime. Political leader Ivars Godmanis was elected as the first Prime Minister of Latvia. He was also one of the leaders of Latvijas Tautas Fronte. This time was full of challenges, transition from command economy to free market, collapse of economic and financial system, introduction of new currency and privatization. Also Russian army troops were still in Latvia. He continued to serve as a Prime Minister until 1993, afterwards he joined several businesses and returned to politics in 1998. He has been both the leader of the political party Latvijas Cel̦š (Latvian Way) and has served as a minister of Interior. In 2007 for two years Ivars Godmanis was a Prime Minister of Latvia and as from 2009 he was elected to the European Parliament. Now he is a consultant and transfers his leadership skills and great knowledge to young professionals.

These above mentioned political leaders can be attributed to the narrow concept formulated by Joseph Schumpeter (Nicolas, 1981, p. 121), were he states that the democracy is a political method for political leadership. People can choose political leaders during election process, while all other time the decisions are made by politicians.

\section{Legal Principles of Democracy in Latvia}

Latvia's Constitution, Satversme, Article 1, states that Latvia is a Democratic Republic. It means that one of the constitutional identity elements is the democratic principle. The most important person in a democracy is a loyal citizen with freedom to form and join organizations and political parties, freedom of expression, right to vote, information source diversity, free and open elections and freedom of choice.

Since restoration of independence in the early 1990s, a certain consensus has formed in the Latvian society regarding the constitutional foundations of the state, particularly about the role of the Constitution of the Republic of Latvia of 1922. The Constitution that was adopted in 1922 laid down the foundations of the state system: general rules of the state, as well as provisions in relation to the forming of the Saeima, the President and the Cabinet of Ministers, and to their activity Special laws regulate sectorial matters.

Since 2004, several attempts have been made to introduce new norms in the Constitution that would influence important determinations of the Latvian society. In 2014, Latvian Parliament adopted the Preamble of the Constitution in the third and final reading. The Preamble lays down that the state of Latvia was established "upon the unamendable will of the Latvian nation for its own state and its inalienable right to self-determination in order to guarantee the existence of the Latvian nation through the ages, preservation and development of the Latvian language and culture, and prosperity of every human being and people of Latvia as a whole" (Rozenvalds, 2014, p. 36). The preamble perpetuates the historical experience of the 20th century and the restoration of independence; Latvia is characterized as a socially responsible national state that respects the principles of democracy and the rule of law which protects human rights and honors national minorities. ${ }^{3}$ The

\footnotetext{
${ }^{2}$ Retrieved June 20, 2016, from http://www.nacionalaapvieniba.lv/par-mums/vesture/tblnnk-vesture/

3 Retrieved June 6, 2016, from

http://www.la.lv/satversmes-preambula-nosaka-ka-latvija-izveidota-latviesu-nacijas-pastavesanas-garantesanai/
} 
preamble also emphasizes Latvian and Liv (Livs are one of the Finno-Ugric nations of the Baltic Sea who earlier occupied a wide territory of Latvia, but now only occupy 12 villages-Ovīši, Lūžņa, Miķeļtornis, Lielirbe, Sīkrags, Mazirbe, Košrags, Pitrags, Saunags, Vaide, Kolka and Melnsils) traditions, the Latvian life wisdom, the Latvian language, human and Christian values, as well as Latvia's identity in the European cultural space.

First Parliamentary elections after independence was restored in 1991 for the Fifth Saeima (the Parliament) were held in Latvia in June $1993^{4}$. Political party Latvijas Ceļš (Latvian Way) emerged as the largest party in Saeima (the Parliament), winning 36 of the 100 seats. A total of 23 political parties participated in the elections, eight of them received four percent or more of votes and won seats. Voter turnout was the highest in Latvia's history 91.2\%. Anatolijs Gorbunovs, one of Latvijas Cel̦š founders continued to serve as the Speaker of the Parliament (Saeima) until 1995. Later, during sixth and seventh Saeima Anatolijs Gorbunovs was the Member of the Parliament having different roles, also served as a Minister of Regional Development, later as a Minister of Transportation and Deputy Prime Minister. Now he is a pensioner, who has had a great political career and has the great impact of the democratization in Latvia.

In 1994 there were bank crisis in Latvia and the internal political situation became aggravated. The Law of Citizenship was adopted and the new norms of naturalisation took place which started at the beginning of 1995. Never the less this issue remained live for several years and in 1998 the Parliament of Latvia adopted the amendments to this law which facilitated the naturalisation process. However, in 1998 there was a referendum against these amendments with the result of $52.5 \%$ against and $44.9 \%$ for, and they were adopted.

In late 1990s, the economic growth of Latvia became significant. Latvia's economy has had rapid Gross Domestic Product (GDP) growth of more than 10\% per year during, but entered a severe recession in 2009 as a result of an unsustainable current account deficit, collapse of the real estate market, and large debt exposure amid the softening world economy.

After the application of the Membership in European Union in 1995, Latvia was recommended by the European Commission to open negotiation process in late 1999. The referendum on European Union membership was held in 2003. 67.5\% voted for and 32.5\% voted against. The above mentioned Einars Repše was the Prime Minister at that time. He put on a blue EU T-shirt and said "Latvians understand this is a decisive moment". The State President (1999-2003) Vaira Vīķe Freiberga described the result as a "wiping out forever the divisions on the map of Europe that the Molotov-Ribbentrop Pact of 1939 placed here" ${ }^{\circ}$. Latvia became a member state of NATO in March 2004 and member state of EU in May 2004.

In 2014, Latvia joined the Euro area. Before EUR, Latvia had Latvian lats which joined the Exchange Rate Mechanism (ERM II) in 2005, and observed a central rate of 0.702804 to the euro with standard fluctuation margins of \pm 15 , but Latvia unilaterally maintained a one percent fluctuation band around the central rate. ${ }^{6}$

\section{Measuring Democracy}

The level of democracy according to Human Rights organization "Freedom House" latest annual survey in $2016^{7}$ about democracy in 29 Central Europe and Eurasia, determines that Latvia has been recognized as the

\footnotetext{
${ }^{4}$ Retrieved June 1, 2016, from https://www.cvk.lv/pub/public/27483.html

5 Retrieved June 30, 2016, from http://news.bbc.co.uk/2/hi/europe/3126100.stm

${ }^{6}$ Retrieved June 30, 2016, from http://ec.europa.eu/economy_finance/euro/countries/latvia_en.htm

7 Retrieved June 30, 2016, from http://freedomhouse.org/report/nations-transit/nations-transit-2016
} 
third democratic country in the region, however the high level of corruption has been mentioned as a threat. Latvia has received 2.07 points out of seven, were one is the highest rank. It is mentioned that countries and territories with a rating of two have slightly weaker political rights than Estonia (1.93), but both countries are close to each other, because of such factors as political corruption, limits on the functioning of political parties and opposition groups, and foreign or military influence on politics. The Latvian constitution provides for a unicameral, 100-seat parliament, whose members are elected to four-year terms. The parliament elects the president, who serves up to two four-year terms. The prime minister is nominated by the president and approved by the parliament. Elections are considered free and fair. Latvia's political parties compete freely. Latvian political candidates cannot run as independents, and those who belonged to communist or pro-Soviet organizations after 1991 may not hold public office. Saskanascentrs (Harmony Center) which has acquired most of the votes in parliament (24 out of 100) has never been invited to participate in a coalition government.

\section{Conclusions}

Since the formation of democracy, Latvia has had several political leaders who led Latvia towards democratic state, however these leaders are not on the political stage currently. Anatolijs Gorbunovs left politics giving possibility and enhancing to younger generation and it is because of age, like Anatolijs Gorbunovs, some of them left the politics, like Einārs Repše, some serve in foreign sector, like Indulis Bērziņšs. It was an important time for the country and these leaders needed such abilities, like flexibility to process the information, negotiation skills, orientation towards goal achievement, judgement and decision making, emotional intelligence, people management, critical thinking, complex problem solving and the most important the patriotism. The formation of democracy was stated in each (20) government declarations as from 1990 around three times, this allows to conclude that there is gap and a necessity for political leaders to integrate this term and seriously follow the obligations which comes together with democracy.

Democracy itself does not guarantee anything. It offers instead the opportunity to succeed as well as the risk of failure. It is both the promise, that people living together can govern themselves and act for freedom, economic and social growth and independence of speech, and the challenge, because the success depends on unity and hard work together towards common goal.

\section{References}

Dahl, R. A. (2000). On democracy. New Haven: Yale University Press.

Held, D. (1996). Models of democracy. Cambridge: Polity Press.

Jundzis, T. (2006). Development of democracy: Experience in the Baltic States and Taiwan. Latvian Academy of Sciences, Taiwan Foundation for Democracy, Riga, Elpa.

Maiolo, F. (2007). Medieval sovereignty: Marsilius of Padua and Bartolus of Saxoferrato. Delft: Eburon.

Nicolas, X. (1981). Classics of democracy: Democracy as method. A Journal of Political Renewal and Radical Change, 1(4).

Rozenvalds, J. (Eds.). (2006). How democratic is Latvia? Audit of democracy 2005-1014. University of Latvia, Social and Political Research Institute. Retrieved June 6, from http://www.szf.lu.lv/fileadmin/user_upload/szf_faili/Petnieciba/Demokratijas_audits_2014_kopaa.pdf

Sorensen, G. (1993). Democracy and democratization: Processes and prospects in a changing world. Boulder, CO: Westview Press. 